\title{
A!
}

This is an electronic reprint of the original article.

This reprint may differ from the original in pagination and typographic detail.

Artto, Karlos; Kujala, Jaakko

\section{Project Business as a research field}

Published in:

International Journal of Managing Projects in Business

Published: 01/01/2008

Document Version

Peer reviewed version

Please cite the original version:

Artto, K., \& Kujala, J. (2008). Project Business as a research field. International Journal of Managing Projects in Business, 1(4), 469-497.

This material is protected by copyright and other intellectual property rights, and duplication or sale of all or part of any of the repository collections is not permitted, except that material may be duplicated by you for your research use or educational purposes in electronic or print form. You must obtain permission for any other use. Electronic or print copies may not be offered, whether for sale or otherwise to anyone who is not an authorised user. 
Artto K., \& Kujala J. (2008). Project business as a research field, International Journal of Managing Projects in Business

MPiB-08043

\title{
Project business as a research field
}

\author{
Karlos Artto, Prof. \\ Helsinki University of Technology (HUT), Finland \\ Industrial Management \\ P.O. BOX 5500, FI-02015 HUT, Finland \\ Tel: +35894514751 \\ Email: karlos.artto@hut.fi \\ $\&$ \\ Jaakko Kujala, Prof. \\ University of Oulu, Finland \\ Industrial Management \\ P.O. BOX 4610, FI-90014 University of Oulu, Finland \\ Tel: + 358408391717 \\ Email: jaakko.kujala@oulu.fi
}

\section{Abstract}

Purpose: This paper introduces project business as a research field. The project business view in this paper puts focus on the management of firms and their businesses, and this way the paper complements the existing project-centric view of the role of projects and their management in various business contexts.

Design/methodology/approach: We propose a conceptual framework for project business and identify relevant research areas and themes. These research areas and themes are derived by using the knowledge and experience obtained from scientific project business research conducted in Finland since the early 1990s.

Findings: This paper describes project business as a research field by introducing a project business framework and the four major research areas inherent in the framework: 1. management of a project, 2. management of a project-based firm, 3. management of a project network, and 4. management of a business network. We also suggest specific research areas and themes within the framework that are relevant and contribute to new knowledge in the project business field.

Practical/research implications: The project business framework described in this paper, including the suggested research areas and themes, is important in focusing research and for development of practical application of project-based business activities in firms and in public organizations.

Originality/value: The paper reveals avenues that lead towards the development of a new body of knowledge for project business that focuses on managing both firms and projects effectively in their networked business environments.

Keywords: Project business, project, project management, project-based firm, project network, business network

Paper type: Research paper 


\section{Introduction}

The significance of project business is increasing. Today, project-based business activities are part of all private firms and public organizations. Although existing studies analyze projects, firms, and business, and practitioners increasingly refer to project business, the concept of project business as a research field has remained ambiguous. The contemporary critical project research attempts to seek new perspectives to projects and their management by adopting a rather project-centric point of departure; in addition, many existing critical project studies focus on organizational issues. This paper complements these existing project-centric and organizational views by concentrating primarily on the management of firms and their businesses.

The approach of this paper is to analyze the project business field and simultaneously to provide an original definition for project business through its relevant themes. This paper has two objectives: 1) to describe project business as a research field through introducing a project business framework and the four major inherent research areas, and 2) to suggest specific research areas and themes that are relevant and contribute to new knowledge in the project business field.

This paper is divided into two parts that are in line with the two objectives. The first part introduces a project business framework that makes a distinction between four major areas. In the second part of the paper the project business framework is applied to analyze project business as a research field. We suggest relevant research areas and themes by analyzing existing and emerging research. Our analysis is facilitated by the use of the knowledge and experience from the scientific project business research conducted in Finland since the early 1990s. The conclusions of the paper is a description of the whole project business research field by means of several specific research areas that are considered relevant for future research and also for empirical application in firms and in public organizations.

\section{Project business framework}

Project research is expanding its view towards wider aspects of project business. Artto \& Wikström (2005) define it as: "Project business is the part of business that relates directly or indirectly to projects, with the purpose of achieving objectives of a firm or several firms." This definition refers to multiple projects and multiple firms. Also Söderlund (2004) uses the dimensions of single vs. multiple projects, and single vs. multiple firms, while categorizing project research published recently in one mainstream project management journal and in major management and organization journals. Engwall (2003) emphasizes the imperative of understanding the project's context and not simply the project as an isolated whole.

Indeed, both projects and firms are organizational entities that represent relevant players in the business context. Furthermore, the business contents of multiple projects and multiple firms are often related in a complex manner. The project business framework in Figure 1 
illustrates major areas of research and of managerial application with a single and with several firms, and with a single and with several projects that may cross one or several firms' business activities. The project business framework illustrates four distinctive areas under the headings: 1 . management of a project, 2. management of a project-based firm, 3 . management of a project network, and 4. management of a business network. The areas differ as to whether the object of the management is a project, a project-based firm, a project network, or a business network.

$\begin{array}{ll}\text { One } & \text { Many } \\ \text { firm } & \text { firms }\end{array}$

\begin{tabular}{l|l|c|}
\cline { 2 - 3 } $\begin{array}{l}\text { One } \\
\text { project }\end{array}$ & $\begin{array}{c}\text { 1. Management of a } \\
\text { project }\end{array}$ & $\begin{array}{c}\text { 3. Management of } a \\
\text { project network }\end{array}$ \\
\cline { 2 - 3 } $\begin{array}{l}\text { Many } \\
\text { projects }\end{array}$ & $\begin{array}{c}\text { 2. Management of a } \\
\text { project-based firm }\end{array}$ & $\begin{array}{c}\text { 4. Management of } a \\
\text { business network }\end{array}$ \\
\hline
\end{tabular}

Figure 1. Framework of project business: four distinctive management areas

The management of a project is an area which is well-researched. The existing extensive research in this area makes the field of management of a single project rather well known. This well-known project management knowledge has been developed throughout the last 60 years of modern project management (Morris, 1994). The standard documents of project management currently issued by international project management organizations represent an excellent overview of what the management of a single project includes in its application area (ISO, 1997; PMI, 2004; IPMA, 2006; APM, 2006). International project management organizations have built their own project management guidelines upon knowledge areas (or processes) included in project management, which should prove useful for project management practitioners and for company users (Morris, Crawford, Hodgson, Shepherd, \& Thomas, 2006). It is typically maintained that project management consists of the following broad areas of knowledge (or processes) that all include procedures, methods, and tools that are characteristic of project management: project integration management, scope management, schedule management, cost management, resource and personnel management, communication management, risk management, procurement management, and quality management. These project management knowledge areas are also addressed frequently in the themes of management studies in mainstream project management 
journals. The management of a project area addresses the management of a single project rather than a firm's business, although the existing literature in this area often makes an underlying contextual assumption that the project is conducted under the governance of one parent firm/organization. This area serves as a fundamental basis for the advancement of the research on project business.

The management of a project-based firm is an area which addressing the managerial issues of a firm that conducts a specific part of its activities in a project form. Conducting part of the firm's business through projects may involve projects of two types: external production or customer delivery type projects, and internal development or capital investment projects. For example, a system supplier firm typically runs external customer delivery projects in what can be considered its 'production line' of projects. Furthermore, new product development or process development, or any other innovation activity, are good examples of activities that can be organized in any company in the form of internal development projects. Some firms may conduct just part of their operations in project form even while their primary productive activity might be volume-based or operations-oriented, while some firms may organize most of their internal and external activities in projects (Hobday, 2000). The management of a project-based firm area is a rather new research area that includes research primarily on a firm's management ability and consequently the capacity of the firm to initiate and execute projects that either directly or indirectly benefit the firm's business. Projects are seen as the firm's business vehicles. The management of the projectbased firm area includes research on the project supplier firm's ability to sell and deliver projects to its customers (Cova, Ghauri, \& Salle, 2002), management of innovation (Gann $\&$ Salter, 2000), and research on project portfolios (Archer \& Ghasemzadeh, 1999) and development programs (Pellegrinelli, Partington, Hemingway, Mohdzain, \& Shah, 2007). The management of a project-based firm area addresses managerial activities of a firm that are in place for governing/managing multiple simultaneous or sequential projects for the firm's business purposes.

The management of a project network is a management area that covers a network including several firms and other organizations from different businesses and from different institutional environments that are participating in a project. The network of firms and other organizations participating in a single project is called a project network (Hellgren \& Stjernberg, 1995), a project-based enterprise (DeFillippi \& Arthur, 1998), or a project coalition (Winch, 2006). The management of a project network area represents an area of novel research themes that relate to interpreting a project as a multi-organization enterprise (Grün, 2004) that involves a complex network of firms and other actors in its execution. A project network has an intentionally constructed core of actors that participate in the project (Williams, 2002), however, a project network may also include other actors that are the project's stakeholders (Floricel \& Miller, 2001). A project network is a temporary endeavor which includes several phases, each of which are different in nature (Morris \& Hough, 1987; Slevin \& Pinto, 1987), and is a continuously evolving constellation of actors in ever-changing roles (Eccles, 1981; Dubois \& Gadde, 2000). These characteristics make project networks highly dynamic. The management of a project network area addresses the management of the temporary project across multiple participating firms and other actors that each have their own (and obviously controversial) objectives, interests and expectations from the project, as based on each actor's different business objectives in their permanent businesses. 
The management of a business network is another area which includes novel research themes that relate to several firms' activities, where the firms engage from time to time in mutual projects. The actors in the business network can have aims that are synergistic, and accordingly, there is room for partnership and collaboration (Davis, 2006; Arroyo \& Walker, 2008; Davis \& Walker, 2008). It can also be the case that the aims of the actors in the business network are contradictory and conflicting, which implies adverse relationships, competition or rivalry. Networked firms and their business relationships affect the selection of participating firms in a project, and vice versa, the projects have an impact on the permanent businesses network (Eccles, 1981; Håkansson, Havila, \& Pedersen, 1999). Firms may participate in different projects in different roles, and each project may have different set of actors (Eloranta, 2007). Project supplier firms may engage in several sequential or parallel global projects through different delivery scopes (Cova, Ghauri, \& Salle, 2002). The roles of the actors may change from one project to another, making a partner company in one project a competitor in the next project, or the customer in one project a supplier in the next project. Hellgren \& Stjernberg (1995) argued that there is a dual relationship between project network actors, while organizations have a simultaneous mixture of opponent and partner relationships: for example, a short term partner may become a competitor in future projects, and vice versa. A business network includes, for example, competitors, financiers, customers and their clients, contractors and their subcontractors, suppliers, designers, architects, manufacturers, service providers, integrators, and consultants (Davies, 2004). We consider the concept of business networks in a broad way by recognizing that non-business actors also belong to the network; examples of such non-business actors are authorities, governments, municipalities, politicians, labor unions, public and citizens' assemblies, and environmentalist groups. The management of a business network area includes activities in a rather open and wide business marketplace including several firms and their business interests. Furthermore, the marketplace includes at any one point in time multiple projects that serve as temporary business vehicles for several firms' permanent businesses.

Based on the discussion above, Table 1 concludes the basic characteristics and the distinctive contents of the four major areas in the project business framework.

Table 1. Characterizing the project business research field: distinctive contents of the four major areas of the project business framework

\begin{tabular}{|c|c|c|}
\hline & $\begin{array}{l}\text { Management } \\
\text { of a project }\end{array}$ & $\begin{array}{l}\text { Management } \\
\text { of a project- } \\
\text { based firm }\end{array}$ \\
\hline Unit of analysis & $\begin{array}{l}\text { Management of a } \\
\text { single project } \\
\text { effectively in its } \\
\text { environment. }\end{array}$ & $\begin{array}{l}\text { Management of a } \\
\text { firm and its } \\
\text { multiple projects a } \\
\text { a whole. }\end{array}$ \\
\hline
\end{tabular}

$\begin{array}{ll}\begin{array}{l}\text { Management } \\ \text { object }\end{array} & \text { A project. } \\ \begin{array}{ll}\text { Managerial } \\ \text { challenge }\end{array} & \begin{array}{l}\text { How to deliver the } \\ \text { project on time, in } \\ \text { budget, and to } \\ \text { specification? }\end{array}\end{array}$

\section{Management of a project network \\ Management of a project as an enterprise through managing multiple firms participating in the project.}

A firm.

How to ensure that projects support the strategy and business objectives

\section{Management of a business network}

Management of a network of actors and their relationships in an open and competitive business marketplace.

A project as a multi-firm network.

How to manage the project enterprise by creating a contractual
A network of firms and their relationships. How to maintain efficiency and innovativeness in the network, and 


\section{Measure of success}

Main actors and decision makers

\begin{tabular}{|c|c|c|}
\hline $\begin{array}{l}\text { Existing body } \\
\text { of knowledge }\end{array}$ & $\begin{array}{l}\text { Project and } \\
\text { program } \\
\text { management, } \\
\text { temporary } \\
\text { organizations. }\end{array}$ & $\begin{array}{l}\text { Project portfolio } \\
\text { management, } \\
\text { project-based } \\
\text { operations, make- } \\
\text { to-order } \\
\text { manufacturing, } \\
\text { project sales and } \\
\text { marketing, project- } \\
\text { based innovation in } \\
\text { firms. }\end{array}$ \\
\hline $\begin{array}{l}\text { Significant } \\
\text { contingency } \\
\text { factors }\end{array}$ & $\begin{array}{l}\text { Project uniqueness, } \\
\text { novelty, } \\
\text { technology, } \\
\text { complexity, pace. }\end{array}$ & $\begin{array}{l}\text { Discontinuity, } \\
\text { interdependence } \\
\text { between projects, } \\
\text { market and } \\
\text { technological } \\
\text { uncertainty. }\end{array}$ \\
\hline
\end{tabular}
manager. of the firm, and how to allocate the firm's scarce resources to projects?

arrangement that enhances goal alignment and coordination across multiple firms participating to the project?

Meeting of project's goals with simultaneous achievement of expectations and business objectives of the firms participating in the project.

Project manager. Business unit Owner.

\section{Procurement and} supply chain management, systems integration.

Participating firms, asymmetry of their objectives, interests and identities. how to position the firm in the value network?

Competitiveness and capability of individual firms and networks to create and implement new projects.

Focal firms in the business network.

Industrial networks, partnerships, alliances, joint ventures, value networks.

\author{
Norms and culture, \\ institutional issues, \\ governance \\ schemes, \\ relationship \\ between firms, role \\ stability.
}

\section{Research areas and themes in project business}

In the following sections, we analyze relevant areas and themes of project business in the four major areas in the project business framework. Our analysis draws mainly from the scientific project business research conducted in Finland. Project-based organizations have played an important role in Finland, where project business was recognized as an specific research field already in the 1990s. The following events are examples of activities of Finnish origin that have increasingly brought the topic of project business into discussions in both contemporary business life and in academic circles: the establishment of a professorship in the area of Project Business since 1996 at the Helsinki University of Technology; the Global Project Business national technology program between 1998-2001, funded by the Finnish Funding Agency for Technology and Innovation; the international Nordnet 1999 conference on the theme of Managing Business by Projects; the international IRNOP 2004 project research conference on Project Business and related themes; the article on What is Project Business in 2005 by Artto \& Wikström (2005), and; the book on Project Business in 2006 by Artto, Martinsuo \& Kujala (2006). 
A special issue of Organization Studies in 2004 focused on project-based forms of organizations and discussed challenges related to various forms of project networks and project ecologies (Sydow, Lindkvist \& DeFillippi, 2004). Recently, the concept of project business has also arisen in many international arenas; this is indicated, for example, by the book The Business of Projects by Davies \& Hobday (2005), since 2008 by Emerald's new journal - the International Journal of Managing Projects in Business, and by the Project Business symposium in the Academy of Management annual meeting in 2008. In addition to these firm-management-focused and business-focused scientific outcomes and events, the research network for 'rethinking project management' (see Winter, Smith, Morris, \& Cicmil, 2006) and 'critical project research' (see Hodgson, \& Cicmil, 2006a, 2006b; Clegg, Pitsis, Marosszeky, \& Rura-Polley, 2006) represent major attempts to challenge traditional views to projects and their management. These 'rethinking' and 'critical project research' movements adopt novel project-centric and organizational views to understanding projects and their contexts in different ways. Our paper could be also thought of to represent an attempt to complement this existing 'rethinking' and 'critical' research through its firmcentric and business-centric views contained in the concept of project business.

\section{Management of a project}

Project management research focuses on the problem of managing a single project effectively and successfully. Management of a single project is an extensively researched area since the emergence of the modern project and program management which took place between the 1930s and 1950s (Morris, 1994). Organizational theories have been widely used in project management research since the 1950s (Stinchcombe \& Heimer, 1985; Morris, 1994). Projects have been increasingly defined and researched as temporary organizations; for example, see 'Project management and temporary organizations' a special issue in the Scandinavian Journal of Management in 1995 (Lundin, 1995; Lundin \& Söderholm, 1995; Packendorff, 1995).

Management of risk and uncertainty (see e.g. Kähkönen \& Artto, 1997; Chapman \& Ward, 2002, 2003; Perminova, Gustafsson, \& Wikström, 2008) has been a widely researched and developed area in contemporary project management research since the 1980s. However, so far the focus on project risk management has been on the internal processes of a welldefined and often hierarchical project management system, rather than on the governance mechanisms of a networked, complex and dynamic system that would rely on an open system view on projects. Contingency theory suggests that project management approaches should be tailored to take into account different situations and different project contexts: Turner \& Cochrane (1993), Shenhar (2001), and Shenhar \& Dvir (2004) are examples of recent studies that compare different effective project management approaches in different environments. The concept of project strategy - referring to the strategy of a single project - is addressed in Morris \& Jamieson (2004), Patanakul, Shenhar, \& Milosevic (2006), Shenhar, Milosevic, Dvir, \& Thamhain (2007), Artto, Kujala, Dietrich, \& Martinsuo (2008), and Artto, Martinsuo, Dietrich, \& Kujala (2008). Inside-out management of a project's interface to its context has been raised in relation to the discussion of moving power towards the edge or towards the project's boundaries effectively. An organization's - e.g. a project organization's - relationship with its context can be thought of in terms of the 'power to the edge' philosophy (Alberts \& Hayes, 2003, 2007; Moffat, 2003) which refers to a network centric organization and network enabled capability for addressing mission challenges in the context. Project's relation to its context is also researched in 
terms of the project's isolation from and integration with its parent organization (Lundin \& Söderholm, 1995; Packendorff, 1995; Martinsuo \& Lehtonen 2007b, 2007c, Lehtonen \& Martinsuo 2008).

Table 2 shows the relevant research areas and their specific themes in the major area of 'management of project'. The common characteristics of all the research areas and themes displayed in Table 2 is that they all put a significant emphasis on the challenge and requirements that the project's environment introduces as to how a single project can be managed effectively.

\section{Table 2. Research areas and themes in the "management of a project" major area}

\section{Research area}

Management of risk and uncertainty

Contingency theory view and systems view on projects

Project strategy

Inside-out management of project's interface to its context

\section{Examples of themes from existing literature}

Risk-related knowledge, learning, understanding and sensemaking (Hawk \& Artto, 1999; Artto, Kähkönen, \& Pitkänen, 2000).

Networked projects with network-related risks and network modeling (Eloranta, Kujala, \& Artto, 2007; Kähkönen, Karvonen, \& Ollus, 2007; Artto, Kujala, Dietrich, Oijala, \& Jahkola, 2007; Artto, Eloranta, \& Kujala, 2008).

Different effective project management approaches in different environments (Turner \& Cochrane, 1993; Shenhar, 2001; Shenhar \& Dvir, 2004; Shenhar \& Dvir, 2007).

A project organization as a system (Cleland \& King, 1968; Sayles \& Chandler, 1971).

Project strategy formulation, project as an implementation vehicle of higher level strategies (Morris \& Jamieson, 2004; Jamieson \& Morris, 2004; Shenhar, Dvir, Guth, Lechler, Patanakul, Poli, \& Stefanovic, 2005; Patanakul, Shenhar, \& Milosevic, 2006).

Project's autonomy and the complexity of project's stakeholder environment as two important determinants of the strategy of a single project (Artto, Kujala, Dietrich, \& Martinsuo, 2008; Artto, Martinsuo, Dietrich, \& Kujala, 2008).

Projects are purposefully isolated from their parent organization (Lundin \& Söderholm, 1995; Packendorff, 1995).

Project's integration with and isolation from the parent organization (Martinsuo \& Lehtonen 2007b, 2007c, Lehtonen \& Martinsuo 2008).

\section{Management of a project-based firm}

Lindkvist (2004) argues that a project-based firm is an organization that conducts most of its work in projects and/or has an emphasis on the project dimension rather than on the functional dimension of its organizational structure and processes. Hobday (2000) makes a distinction between project-based and project-led organizations: according to Hobday, project-led organizations are firms in all types of industries that are undertaking projects as a growing part of their operations even while their primary productive activity might be volume-based or operations-oriented, while project-based organizations organize most of their internal and external activities in projects. However, we adopt a broader definition of project-based firm, by assuming that the definition also covers 'project-led' (Hobday, 2000) firms that undertake projects only as a part of their operations. Conducting or 
enhancing the firm's business through its projects involves projects of two types: external production or customer delivery type projects, and internal development or capital investment projects. There is an emerging research field addressing the management of project-based firms (Artto, Heinonen, Arenius, Kovanen, \& Nyberg, 1998; Turner \& Keegan, 2001; Arenius, Artto, Lahti, \& Meklin, 2002; Artto \& Wikström, 2005; Whitley, 2006; Artto, Martinsuo, \& Kujala, 2006). The conceptual analysis by Artto (2001) provides an overview of the management of a project-based firm and its central concepts and applications by addressing the following questions: how is the project interrelated with other organizational structures such as other projects and the line organization, what roles does a project play in fulfilling the strategic objectives set by the firm's management, and what are the appropriate procedures for managing projects with the purpose of producing a profit. Kujala \& Artto (2000) address performance management in project-based firms by setting targets for individual projects. Project supplier firms may engage in several sequential or parallel global projects through different delivery scopes (Cova, Ghauri, \& Salle, 2002). Artto, Heinonen, Arenius, Kovanen, \& Nyberg (1998) presented a study of global project business by examining Finnish global firms. Today, there is an increasing amount of research and managerial applications concentrating on the management of public organizations as project-based 'firms' (Itäaho \& Artto, 1999; Artto \& Dietrich, 2004; Lindeman, 2007; Martinsuo \& Lehtonen, 2007c, 2007e).

Innovation in project-based firms is an important research area (Gann \& Salter, 2000; Keegan \& Turner, 2002). Artto (2001) and Arenius, Artto, Lahti, \& Meklin (2002) discuss the learning loop of a project firm, which should in an ideal situation integrate both horizontal and vertical learning. Such a learning scheme is probably the most important capability that a project-based firm should have. Learning is also associated with innovation, the uniqueness of each project, and the discontinuity between projects, all require that learning and knowledge sharing have a central role (Sydow, Lindkvist, \& DeFillippi, 2004).

The business of a project-based firm can be addressed through its business model. Kujala, Artto, \& Parhankangas (2007) analyze contingency factors affecting both the choice of a business model for a project-based firm and the performance of its business model. A business model can be considered a statement of how the company makes money (Stewart $\&$ Zhao, 2000) or how technological inputs are transformed into economic outputs (Chesbrough \& Rosenbloom, 2002). A business model with a strategic focus is defined in terms of the logic of profit generation. An operationally-focused business model concentrates on the internal processes that enable the firm to create value, such as production or service delivery methods, administrative processes, resource flows, knowledge management, and logistical streams (Morris, Schindehutte, \& Allen, 2005). The integration of project sales and execution in a global project supplier firm is challenging: the sales organization may be distributed into several local sales offices, whereas the organization responsible for delivery project execution may be more centralized, situated in few locations as specialized project execution units (Lampenius, 2006; Dietrich, Kujala, Lampenius, \& Artto, 2007). The discourse of project marketing identifies central features of the business of a project-based firm. These central features are: the uniqueness of individual projects, the complexity of the project offering and business network, the discontinuity of demand and business relationships between projects, and the considerable extent of financial commitment of the parties (Cova, Ghauri, \& Salle, 2002; Mandjak \& Veres, 1998; Tikkanen, 1998). The broad project marketing discourse can be identified in the IMP (Industrial Marketing and Purchasing) research group related studies on 
relationships and networks in project marketing (Cova, Mazet, \& Salle, 1996; Owusu, 2003; Skaates \& Tikkanen, 2003; Skaates, 2000). Murtoaro \& Kujala (2007) and Kujala, Murtoaro, \& Artto (2007) address various negotiation strategies and joint decision making between project customer and supplier during the sales and delivery process. Procurement and supplier network management is important due to the trend of increased subcontracting and focus on a firm's core capabilities. Indeed, firms and projects are more and more dependent on their suppliers (Walker \& Rowlinson, 2008), and therefore the relational focus in subcontractor selection criteria is relevant (Eloranta, 2007).

Meklin, Lahti, Kovanen, Arenius, \& Artto (1999) introduce a product-oriented approach towards project supplier firms. There is a clear distinction between the concepts of project product and company product (Meklin, Lahti, Artto, \& Arenius, 1999; Hellström, 2005). Hellström (2005) studies modularity in the business of delivering projects. Hellström argues that the products and their modularity do not only apply to physical products, but also to project processes and project organization that represent the ultimate capability to create the desired solution as the outcome of the project. Goods or services produced in a project are often credited with the attribute of complexity as they consist of a large number of interacting parts. The interaction often creates great interdependency, not only from an engineering design perspective, but also in an organizational sense (see e.g. Hobday, 1998; Sosa, Eppinger, \& Rowles, 2003). The choice of product structure and organizational architecture interacts (Henderson \& Clark, 1990; Oosterman, 2001). One key issue is how to align service and project processes with the overall business processes in a project-based firm (Gann \& Salter, 2000). Research on services provided by a system supplier firm is focused mainly on customer value of post delivery services for major system deliveries (Oliva \& Kallenberg, 2003; Helander, 2004). Artto, Wikström, Hellström, \& Kujala (2008) adopt a project supplier view and analyze how services influence the performance of project business.

Project portfolio management research includes a wealth of decision-oriented generic process models for strategy implementation with multiple projects (Cooper, Edgett, \& Kleinschmidt, 1997a, 1997b, 1998a, 1998b; Archer \& Ghasemzadeh, 1999; Artto, Martinsuo, \& Aalto, 2001; Aalto, Martinsuo, \& Artto, 2003). Recent research focuses on portfolio management performance, contextuality of project portfolio management, and the interface between management of individual projects and management of portfolios (Martinsuo \& Lehtonen, 2007a; Müller, Martinsuo, \& Blomquist, 2008). Aaltonen (2008) analyzes co-selection in project portfolio prioritization through a population ecological view on top management's activities with innovation project portfolios.

Table 3 shows the relevant research areas and their specific themes in the major area of 'management of a project-based firm'. From the contents of Table 3 we can draw the conclusion that the management of a project-based firm that is specialized in project operations differs considerably from the management of a firm that conducts repetitive production or routine activities in its business.

\section{Table 3. Research areas and themes in the "management of a project-based firm" major area}

\section{Research area}

Theory of project-based firm and the firm's business

\section{Examples of themes from existing literature}

The business model of a project-based firm addressed through the concept and content of business models (Kujala, Artto, \& Parhankangas, 
model

Learning, capabilities and competencies

\author{
Selling and delivering \\ projects
}

Procurement and supplier network management business of a project-based firm

\section{Portfolio and program management}

Resource management in a project-based firm
2007)

Marketing strategy of a project supplier firm (Tikkanen, Kujala, \& Artto, 2007).

Learning and knowledge sharing as the most important capability that a project-based firm should have (Hawk \& Artto, 1999; Prencipe, \& Tell, 2001; Ruuska, 2005; Maqsood, Finegan, \& Walker, 2006).

Management of flexibility in engineering-construction-procurement (EPC) firms through four distinct groups of core competences: entrepreneurial, technical, evaluative, and relational (Lampel, 2001).

Integration of project sales and execution in a global project supplier firm (Lampenius, 2006; Dietrich, Kujala, Lampenius, \& Artto, 2007).

Project sales and implementation as an integrative negotiation process (Murtoaro \& Kujala, 2007; Kujala, Murtoaro, \& Artto, 2007).

A project contractor's supplier network and the contractor's relationships with its suppliers as an important resource that contribute to the contractor's competitive advantage with customers (Kelly, 2006; Tikkanen, Kujala, \& Artto 2007; Artto, Eloranta, \& Kujala, 2008).

Influence of customer's purchasing strategy on customer's value creation (Eloranta 2007; Laitinen, 2007; Ahola, Laitinen, Kujala, \& Wikström, 2008).

Modularity in the business of delivering projects, and modular project organization (Söderlund, 2002; Hellström, 2005).

The nature of the product and the project as a determinant shaping the project supplier firm's organization (Hobday, 1998; Wikström, Hellström, Artto, Kujala J., \& Kujala S., 2008).

Systems integration and "integrated solutions" for combining system products and services into vast and long-lasting deliverables from a supplier to its customer (Davies, 2004; Hobday, Davies, \& Prencipe, 2005).

The role of services in the business model of project-based firm (Artto, Wikström, Hellström, \& Kujala, 2007, 2008; Kujala J., Artto, Wikström, Kujala S., 2008).

Co-selection in top management's project portfolio prioritization (Aaltonen, 2007, 2008; Aaltonen \& Martinsuo, 2008).

Programs as large multi-organizational maneuvres that relate to large industrial or public sector developments/investments (Pellegrinelli, Partington, Hemingway, Mohdzain, \& Shah, 2007; Dietrich, 2007; Lehtonen \& Martinsuo, 2008; Nieminen \& Lehtonen, 2008); distinctive features and differences between projects and programs and their management (Artto, Martinsuo, Gemünden, \& Murtoaro, 2008).

Resource allocation in multi-project organizations (Engwall \& Jerbrant, 2003; Elonen \& Artto, 2003;Dammer \& Gemünden, 2007).

People working in multi-project organizations perceiving fragmentation, disruption and inefficiency (Zika-Viktorsson, Sundström, \& Engwall, 2006; Allvin, Gustavsson, Packendorff, \& Zika-Viktorsson, 2007). 


\section{Management of a project network}

A project typically involves several organizations for its execution. Therefore, the network perspective when considering a project as a network of multiple firms or organizations is most relevant (Hellgren \& Stjernberg, 1995; DeFillippi \& Arthur, 1998; Floricel \& Miller, 2001; Windeler, \& Sydow, 2001; Sydow, \& Staber, 2002; Eloranta, Kujala, \& Artto 2006; Eloranta, Kujala, \& Artto 2007). Several actors participating in a project network causes uncertainties that are often due to: network effects such as dependence on other actors; interest asymmetries; different identities; missing information; information asymmetry within the network; social and institutional risks, network risks; trying to behave rationally, and; risk management procedures that do not fit into a networked context (Hellgren \& Stjernberg, 1995; Eloranta, Kujala, \& Artto 2006; Klemetti, 2006; Artto, Eloranta, \& Kujala, 2008). The research on large projects and global projects typically capture the idea that the project is a network of several firms and other organizations from different businesses and from different institutional environments participating to the project (Morris \& Hough, 1987; Kharbanda \& Pinto, 1996; Miller \& Lessard, 2001a, 2001b; Williams, 2002; Horii, Yan, \& Levitt, 2004; Orr, 2005; Mahalingam \& Levitt 2007; Ruuska, Artto, Eloranta, \& Lehtonen, 2008; Scott, 2008). A project can also be considered an enterprise that engages several firms and other organizations that relate to its business purpose (Morris, 1983; Grün, 2004; Murtoaro, 2006).

From the supply chain perspective, a project delivery chain is defined as a network entity formed by several projects built in a hierarchical fashion where the supply relationship is depicted with respect to the customer's (or buyer's) project above and the buyersubcontractor relationship to the subcontractor's project below (Artto, Heinonen, Arenius, Kovanen, \& Nyberg, 1998; Kärkkäinen, Holmström, Främling, \& Artto, 2002). Stakeholder management studies in project research adopt a partial network view of the project network around a focal firm/organization. Winch \& Bonke (2002) and Winch (2004) distinguish between proponents and opponents among project's stakeholders. Walker, Bourne \& Rowlinson (2008) discuss stakeholder management in a supply chain type network of actors. Many project stakeholder management studies focus on analysis tools such as the power/interest matrix (Johnson \& Scholes, 1999), stakeholder mapping tools (Winch, 2004), stakeholder categorization and visualization tools (Bourne \& Walker, 2006). The recent research of Eloranta, Kujala, \& Oijala (2008), Eloranta \& Kujala (2008), and Eloranta \& Sivonen (2008) widen the project stakeholder management perspective significantly by analyzing different types of influence strategies of stakeholders and of the focal company (for general stakeholder research, see Freeman, 1984; Donaldson \& Preston, 1995; Mitchell, Agle \& Wood, 1997).

Governance in project networks relate to the management of relationships between the various parties that are engaged in the project that is a temporary multi-organization grouping (Cherns \& Bryant, 1984; Winch, 2006). The meaning of governance is derived from the literature on institutional economics. The early work of Coase (1937) identified the market and the firm modes of allocating resources in a market economy, which insight has developed by Williamson and others in what has become transaction cost economics as one branch of institutional economics (Williamson, 1985). Newer forms of relationships are considered hybrid forms of the hierarchy-market dimension (Spina \& Zotteri, 2000). Based on the above, Winch (2006) defines project's management as the commercial function of selecting and maintaining the appropriate governance arrangements between 
independent firms. A project network is a part of a broader governance framework that includes the context of incentive systems and distribution of risks and resources in the market (Winch, 2006). Incentivization through contracts is emphasized, which implies that contractual relationships and contract organization for a project play central roles (Levitt \& March, 1995; Turner \& Simister, 2001). Related to this definition, Jones, Hesterly, \& Borgatti (1997) introduce what they call a general theory of network governance. Furthermore, Klakegg, Williams, \& Magnussen (2007) discuss characteristics of innovative governance frameworks for public investment projects. In addition to transaction cost economics, agency theory (Eisenhardt, 1989) as another conceptualization of the institutional economics has been suggested as the theoretical foundation for the governance in project networks (Turner \& Müller, 2003; Winch, 2006). Important suggestions about the governance of large projects are as follows. Organizational structure of a project with the use of contractors, the shaping of the project, the project's institutional framework and the capacity of governance and self-regulation are essential (Miller \& Lessard, 2001a, 2001b; Miller 2006). The owner's competences and interests in putting resources into the process and carrying the responsibilities are crucial (Morris \& Hough, 1987; Grün, 2004; Miller, 2006). It is the responsibility of project owners to establish the project management structure (Miller, 2006). For example, based on an empirical evidence from an analysis of a large project, Brady (2007), Brady, Davies, Gann, \& Rush (2007), and Brady (2008) argued that effective principles of governance in the researched megaproject included the following: the owner accepted all relevant risks in the framework agreement (the owner also agreed to partially bear contractors' risks/concerns as to future projects), incentive-based contracts, and interest alignment and identity building of the core integrated team. The financing party's involvement in an early phase is vital, as this helps to shape the project right from the start and the financier's commitment to objectives would guarantee their support when financing the later phases of the project (Flyvbjerg, Bruzelius, \& Rothengatter, 2003; Samset, 2003). Extensive use of contractors release the owner's capacity and enable the owner to concentrate on core tasks (Grün, 2004).

However, the owner should not mix firm prices and reimbursable contract forms, i.e., the owner must not allocate such risks to the contractor that relate more naturally to the owner's business and are therefore more appropriate to keep under the owner's responsibility (Morris \& Hough, 1987). There should be balanced authority and responsibility among the different stakeholders. (Morris \& Hough, 1987; Grün, 2004)

Table 4 shows the relevant research areas and their specific themes in the 'management of a project network' major area. Based on the analysis of the contents of Table 4, it is obvious that the management of a project network with multiple firms introduces a setting that can be considered opposite to the traditional expectations of the mutual roles of projects and firms. This means that traditionally, the firm is considered the focal enterprise and management across its projects with a portfolio view is expected to represent a typical managerial setting. Concerning 'management of a project network' area in Table 4, the situation is the opposite: the project [network] is the focal enterprise, and from the viewpoint of this project enterprise, the challenge is in managing the entire portfolio of firms that are participating in its business scheme.

Table 4. Research areas and themes in the "management of a project network" major area

Research area

Large projects research
Examples of themes from existing literature

A global project with resources from more than one socio-cultural 
Project as network of firms

\author{
Project as multi- \\ organization enterprise
}

\section{Dynamism in project network}

\section{Learning within the project network}

\section{Stakeholder management}

\section{Systems integration}

Project delivery chain and supply chain management within a project system and/or geographical setting (Horii, Yan, \& Levitt, 2004; Orr, 2005; Mahalingam, 2005; Mahalingam \& Levitt 2007; Scott, 2008).

Managing the project by coordinating the activities of various actors across this complex network of organizations and firms (Morris \& Hough 1987; Williams, 2002; Evaristo, Scudder, Desouza, \& Sato, 2004; Ruuska, Artto, Eloranta, \& Lehtonen, 2008).

Projects are temporary networks consisting of several organizations or actors (Eccles, 1981 Hellgren \& Stjernberg, 1995; Dubois \& Gadde, 2000; Eloranta, Kujala, Artto, \& Tikkanen, 2006; Eloranta, 2007).

Risk management procedures in project networks (Klemetti, 2006; Artto, Eloranta \& Kujala, 2008; Kähkönen, Karvonen, \& Ollus, 2007).

A project as multi-organization enterprise (Grün, 2004) with institutional, strategic, and tactical levels of management (Parson, 1960; Morris, 1983)

A project organization constructed through contracts between participating firms (Walker, \& Smith, 1995; Akintoye, Beck, \& Hardcastle, 2003; Davies \& Hobday, 2006; Murtoaro, 2006) for creating a cooperative system (Levitt \& March, 1995; Flyvbjerg, Bruzelius, \& Rothengatter, 2003).

The dynamism in project network due to new actors joining the project in different phases of the project, and continuous change of roles of actors during the project (Hägg \& Johansson, 1987; Powell, 1987, 1990; Eloranta, 2007).

System dynamism in a project as related to causes to disruption and delay, feedback dynamics with vicious circles (Williams, Eden, Ackermann, \& Tait, 1995; Eden, Williams, Ackermann, \& Howick, 2000; Williams, Ackermann, \& Eden, 2003).

A project capability-building model based on the learning scheme within the project (Brady \& Davies, 2004); discovery-oriented project management scheme for intra-project learning (McGrath \& MacMillan, 2000).

Collective competence (Sandberg \& Targama 1998; Hansson 1998; Ruuska, 2005); projects as learning chain opportunities (Maqsood, Walker, \& Finegan, 2007).

Project stakeholder management practices (Winch \& Bonke, 2002; Winch, 2004; Bourne \& Walker, 2006).

Project stakeholders' influence strategies (Eloranta, Kujala, \& Oijala 2008; Eloranta \& Kujala, 2008); focal project organization's strategies to manage its stakeholders (Eloranta \& Sivonen, 2008).

Systems integration as a project management capability (Hobday, Davies, \& Prencipe, 2005).

Technical team interaction in product development (McCord \& Eppinger, 1993; Pimmler \& Eppinger, 1994; Sosa, Eppinger, Rowles, 2003).

Project delivery chains composed of contractors' delivery projects to their customers, the owner's investment project being the ultimate downstream end point of the delivery chain (Artto, Heinonen, Arenius, Kovanen, \& Nyberg, 1998; Kärkkäinen, Holmström, Främling, \& Artto, 2002).

Members of the supply chain (tier 1 , tier $2, \ldots$ etc. suppliers) receiving the client's value system and contributing to client's value chain (Kelly, 2006). 
Governance in project network
Governance in project network relating to the management of relationships between the various parties engaged in the multiorganization project (Cherns \& Bryant, 1984; Winch, 2006).

Governability (Floricel \& Miller, 2001) as a group of properties that enables the project to react to unexpected events; governability complements the notion of flexibility (Bettis \& Hitt, 1995).

\section{Management of a business network}

In general, the increase of networks of organizations is due to: increased outsourcing, liberalization and de-regulation, the challenge of complexity and scattering of various special capabilities to several organizations, technological convergence, solutions in information and communication technologies, and digitization. The business relationships in the permanent business network of firms affect the composition of those firms that are selected to participate in a project, and vice versa, the projects and their temporary networks have an impact on the permanent business network (Eccles, 1981; Hellgren \& Stjernberg, 1995; Håkansson, Havila, \& Pedersen, 1999; Dubois \& Gadde, 2001; Beach, Webster, \& Campbell, 2005; Ahola, Kujala, Laaksonen, \& Eloranta, 2006; Arroyo \& Walker, 2008; Artto, Eloranta, \& Kujala 2008). Also facilitating government or institutional agencies may serve in the central role of business incubators that affect the project constellations (Doz, \& Hamel, 1998; Porter, 1998). Grabher (2002, 2004) acknowledges the importance of project ecologies or regional agglomerations of project based organizational and institutional participants; the 'project ecologies' arena is where economic geographers are contributing to understanding of project business as an interorganizational phenomena. The firms may participate in different projects in different roles, and each project may have separate set of actors (Eloranta, Kujala, Artto, \& Tikkanen, 2006; Eloranta, 2007). Furthermore, a project supplier firm's delivery scopes vary in those several sequential or parallel projects that the supplier firm engages in (Cova, Ghauri, \& Salle, 2002). Interests and goals between business actors or non-business actors in the business network can be controversial, conflicting or competitive, which may introduce barriers to a project's activities, or political behavior that complicates the execution of a project in a setting where different parties try to use their power to impact the project so that it will be in accordance to their business interests (Lamberg, Pajunen, Parvinen, \& Savage, 2008).

There are several business strategies that the project firm can use for effectively competing in the global projects marketplace (e.g., Mintzberg, Quinn, \& Ghoshal, 1995; Floricel \& Miller, 2001; Walker, Bourne \& Rowlinson, 2008). Performance measurement in multifirm supply network is relevant for obtaining a perspective across several firms about their collaborative and competitive positions in the business network; Kujala, Ahola, Westerholm, Lehtonen, Laitinen, \& Artto (2007) introduce a performance measurement system design that also includes performance measurement at the business network level in multi-firm supply networks. Project delivery business is characterized by discontinuity, which means that between two active sales and delivery projects there is a 'no project' phase - or "sleeping phase" - that introduces discontinuity to the relationships between the project customer and the project supplier (Hadjikani, 1996; Cova, Ghauri, \& Salle, 2002). Many project supplier firms have included a wide set of services in their offerings in order to overcome the challenges caused by discontinuity. One purpose of such wide service offering is to make the firm's activities and business relationships with other parties in the 
wide business network more continuous (Artto, Wikström, Hellström, \& Kujala, 2008). A significant strategic question for companies involved in project activities in the business network is, where in the value stream does the company want to concentrate its valueadding activities (Davies, 2004; Davies \& Hobday, 2006)? A firm's search for its position in the value stream with potential downstream moves relates to the discussion of the role of services in the business of a project-based firm.

Table 5 shows the relevant research areas and their specific themes in the 'management of business network' major area. Based on the content of Table 5, we can conclude that the business network represents a dynamic context for firms and projects that are characterized by various parties and their various business interests. In this dynamic environment both competition and collaboration, and both conflicting and synergistic interests and activities occur simultaneously at the level of projects, firms, and their partial networks.

\section{Table 5. Research areas and themes in the "management of a business network" major area}

\section{Research area \\ Interplay between \\ temporary project networks and the permanent business network}

\section{Measurement of performance in business network}

Analysis of networked business environment and design of the firm's strategy

Ever-changing roles of the network's players

Multiple conflicting interests and fragmented entities even within one single firm

\author{
Examples of themes from existing literature \\ Two-way impacts between the permanent business network and the \\ temporary project networks (Ahola, Kujala, Laaksonen, \& Eloranta, \\ 2006; Eloranta, Kujala, Artto, \& Tikkanen, 2006; Eloranta, 2007; Artto, \\ Eloranta, \& Kujala, 2008). \\ Discontinuity of customer relationship due to a "sleeping phase" \\ between project deliveries (Hadjikani, 1996; Cova, Ghauri, \& Salle, \\ 2002); overcoming the challenges caused by discontinuity through \\ services (Artto, Wikström, Hellström, \& Kujala, 2008; Kujala J., Artto, \\ Wikström, \& Kujala S., 2008).
}

Measurement of elements contributing to value and destroying value of network actors (Laitinen, 2007; Ahola, Laitinen, Kujala, \& Wikström, 2008).

Performance measurement system for project business networks (Kujala, Ahola, Westerholm, Lehtonen, Laitinen, \& Artto, 2007).

Milieu analysis as a tool for the company to acquire information about the functioning of the network of business and non-business actors related to the project's business environment (Cova, Mazet, \& Salle, 1996; Cova, Ghauri \& Salle, 2002).

Constructivistic marketing approach for shaping the business network and positioning the firm in the network (Cova \& Hoskins, 1997; Tikkanen, Kujala, \& Artto, 2007).

Different roles of the actors from one project to another: one's partner company in a project may be a competitor in the next project, or one's customer in one project may become one's supplier in the next project (Hellgren \& Stjernberg, 1995; Eloranta, 2007; Artto, Eloranta, \& Kujala, 2008).

Projectized innovation in complex products and systems requires a unique constellation of business players participating to each project (Miller, Hobday, Leroux-Demers, \& Olleros, 1995; Hobday, 1998).

Conflicting managerial objectives at the project level and at the business level in a project-based firm affect in a controversial manner the management of business relationships with external network partners (Artto, Eloranta, \& Kujala, 2008).

Different objectives at the project and business levels concerning open 
Embedded innovation in business activities in the network

Moving base in the value stream information sharing with partners in the supplier network (Hirvonen, 2005).

Major systems deliveries are innovations that are conducted in a project form jointly with a network of several firms and organizations (e.g. Davies \& Hobday, 2005; Shenhar \& Dvir, 2007).

Project and business networks are ideal platforms when enhancing the power of the network by adopting the principles of open innovation (Chesbrough, 2003; Dahlander \& Wallin, 2006; Chesbrough, Vanhaverbeke, \& West, 2006), open source (Haefliger, von Krogh, \& Spaeth, 2008), or open business models (Chesbrough, 2006).

Companies are moving downstream in the value chain towards services, to where the money is (Wise \& Baumgartner, 1999).

Buyers of capital goods are entering into long-term partnerships with their suppliers to ensure that providers of solutions share the responsibility and risks of performing outsourced activities. (Davies, 2004; Davies \& Hobday, 2006).

Companies completely re-aligning and reconfiguring their relationships on jointly delivered streams of projects (Davis, 2006; Arroyo \& Walker, 2008; Davis \& Walker, 2008)

\section{Conclusion and further research}

In this paper we introduced a project business framework, which was applied to describe project business as a research field. The project business research field includes several specific research areas and themes that are relevant for future research (Figure 2). These research areas also reflect practical management areas that should be the developmental focus for future management applications in today's industries and in the public sector.

\begin{tabular}{|c|c|}
\hline $\begin{array}{l}\text { 2. Management of a project-based firm } \\
\text { •theory of project-based firm and the firm's business model } \\
\text {-learning, capabilities and competencies } \\
\text {-selling and delivering projects } \\
\text {-procurement and supplier network management } \\
\text {-the role and management of products in the business of a } \\
\text { project-based firm } \\
\text {-the role of services in the business of a project-based firm } \\
\text {-portfolio and program management } \\
\text {-resource management in a project-based firm }\end{array}$ & 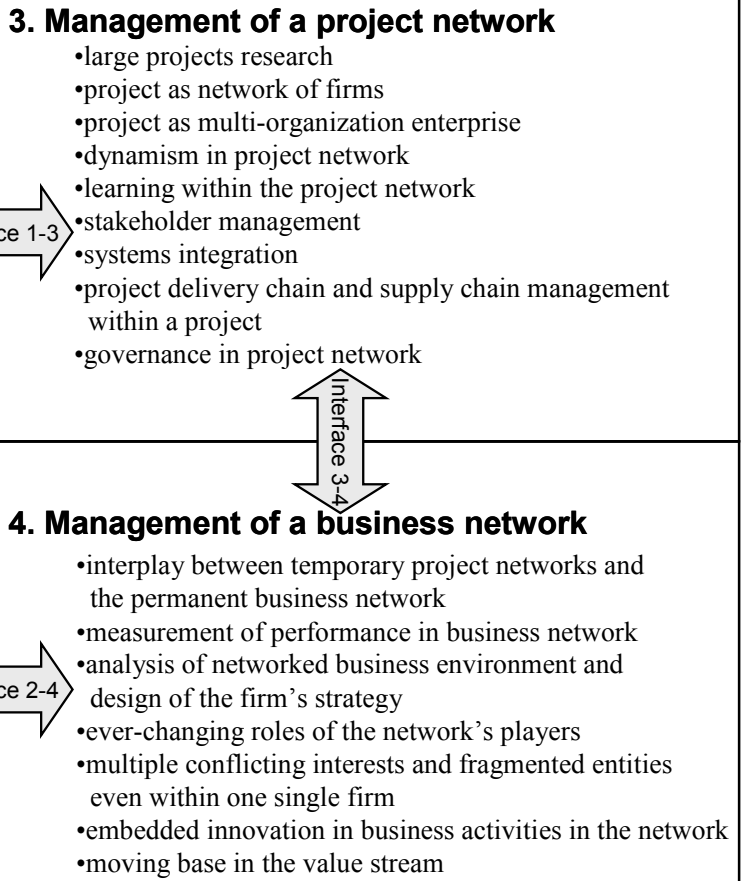 \\
\hline
\end{tabular}

Figure 2. Project business framework with specific research areas and themes 
We welcome future studies that will expand both the scientific and practice-oriented foundations of project business. Especially, we suggest three areas for further research. First, we suggest that future research should elaborate on the content of the project business framework, by analyzing recent relevant research content not only within each of the four major areas (as we did in this paper), but also within each of the four interfaces in between the four major areas (the four interfaces are marked in Figure 2). Second, further research should also seek various scientific foundations for each research area in the project business framework. Third, new knowledge is needed about the inherent system dynamism, cause-effect chains, feedback loop dynamics, vicious or virtuous circles, and the relationships between various parameters within the areas and interfaces of the project business framework.

\section{References}

Aalto T., Martinsuo M., \& Artto K. A. (2003). Project portfolio management in telecommunications R\&D: aligning projects with business objectives, pp. 99-147, In: Korhonen T. O., \& Ainamo A. (eds.) Handbook of product and service development in communication and information technology, Kluwer Academic Publishers, Boston

Aaltonen P. (2007). On co-selection in project portfolio prioritization: a population ecological analysis of the influence of top management on innovation project portfolio outcome, Doctoral Seminar on Project Business, Helsinki University of Technology and Åbo Akademi University, Nov 22-23, 2007, Espoo, Finland

Aaltonen P. (2008). Co-selection in project portfolio evolution: an intra-firm ecological analysis, Annual Meeting of the Academy of Management, August 8-13, 2008, Anaheim, California

Aaltonen P., \& Martinsuo M. (2008). Prioritization decisions and portfolio evolution in project portfolio management, European Academy of Management EURAM, 8th Annual Conference, May 14-17, 2008, Ljubljana \& Bled, Slovenia

Ahola T., Kujala J., Laaksonen T., \& Eloranta K. (2006). The long-term interorganizational relationships in project business. Proceedings of the Seventh International Conference of the International Research Network on Organising by Projects IRNOP VII, October 11-13, 2006, Xi' an, China, 52-69

Ahola T., Laitinen E., Kujala J., \& Wikström. (2008). Purchasing strategies and value creation in industrial turnkey projects, International Journal of Project Management, 26(1): $87-94$

Akintoye A., Beck M., \& Hardcastle C. (2003). Public-Private Partnerships: managing risks and opportunities, Oxford, Blackwell Science Ltd

Alberts D. S., \& Hayes R. E. (2003). Power to the edge: command and control in the information age. DoD command and control research program CCRP publication series, U.S. (can be downloaded from the Program's website at http://www.dodccrp.org/ -> book downloads) 
Alberts D. S., \& Hayes R. E. (2007). Planning: complex endeavors. DoD command and control research program CCRP publication series, U.S. (can be downloaded from the Program's website at http://www.dodccrp.org/ -> book downloads)

Allvin M., Gustavsson T. K., Packendorff J., \& Zika-Viktorsson A. (2007). What next? - an empirical study on project overload and the need for strategies in a multi project context. Paper presented at the NFF Nordic Academy of Management conference, 9-11 August, 2007, Bergen, Norway

Archer N., \& Ghasemzadeh F. (1999). An integrated framework for project portfolio selection, International Journal of Project Management, 17(4): 207-216

Arenius M., Artto K. A., Lahti M., \& Meklin J. (2002). Poject companies and the multiproject paradigm: a new management approach, In: Slevin D. P., Cleland D. I., \& Pinto J. K. (eds.). The frontiers of project management research, Project Management Institute, PMI, USA (503 p.), 289-307

Arroyo A., \& Walker D. H. T. (2008). Business transformation through an innovative alliance, 423-444, Procurement systems - a cross industry project management perspective, Abingdon, Oxon, Taylor \& Francis

Artto K. A. (2001). Management of project-oriented organization - conceptual analysis, In: Artto K. A., Martinsuo M., \& Aalto T. (eds.) Project portfolio management: strategic management through projects, Project Management Association Finland, Helsinki, 176 p., pp. $5-22$

Artto K., Eloranta K., \& Kujala J. (2008). Subcontractors' business relationships as risk sources in project networks, International Journal of Managing Projects in Business, 1(1): 88-105

Artto K., Heinonen R., Arenius M., Kovanen V., \& Nyberg T. (1998). Global project business and the dynamics of change, Technology Development Centre Finland and Project Management Association Finland, Helsinki, Finland, 147 p.

Artto K., Kujala J., Dietrich P., \& Martinsuo M. (2008). What is project strategy?, International Journal of Project Management, 26(1): 4-12

Artto K., Kujala J., Dietrich P., Oijala T., \& Jahkola O. (2007). Analysis of project risk management in the National Aeronautics and Space Administration (NASA), Research report, NASA Ames Research Center, version 1.0, December 31, 2007

Artto K., Kähkönen K., \& Pitkänen P. (2000). Unknown soldier revisited: a story of risk management, Project Management Association Finland, Helsinki, 114 p.

Artto K., Martinsuo M., Dietrich P., \& Kujala J. (2008). Project strategy: strategy types and their contents in innovation projects, International Journal of Managing Projects in Business, 1(1): 49-70 
Artto K., Martinsuo M., Gemünden H. G., \& Murtoaro J. (2008). Foundations of program management: a bibliometric view, International Journal of Project Management (forthcoming in November 2008)

Artto K., Martinsuo M., \& Kujala J. (2006). Project business, Publisher: WSOY, Helsinki, Finland, 416 pages, in Finnish

Artto K. A., \& Wikström K. (2005). What is project business?, International Journal of Project Management, 23(5): 343-353

Artto K., Wikström K., Hellström M., \& Kujala J. (2008). Impact of services on project business, International Journal of Project Management, (forthcoming 2008)

Beach R., Webster M., \& Campbell K. (2005). An evaluation of partnership development in the construction industry, International Journal of Project Management, 23(8): 611-621

Bettis R. A., \& Hitt M.A. (1995). The new competitive landscape, Strategic Management Journal, 16: 7-19

Bourne L., \& Walker D. (2006). Using a visualizing tool to study stakeholder influence two Australian examples, The Project Management Journal, 37(1), 5-21

Brady T. (2007). Learning to deliver a mega project: the case of Heathrow terminal 5, International seminar on "New Project Organizations - Structure, Values, Trust and Reflection”, organized by St. Petersburg State University \& Åbo Akademi University, 1819 of June, 2007, St.Petersburg

Brady T. (2008). Learning to deliver a mega project: the case of Heathrow terminal 5, In: Kosheleva S., Minina V., \& Wikström K. (eds.). New project organizations - structure, values, trust and reflection, St. Petersburg State University \& Åbo Akademi University, St. Petersburg, Russia

Brady T. \& Davies A. (2004). Building project capabilities: from exploratory to exploitative learning. Organization studies, 25(9): 1601-1621

Brady T., Davies A., Gann D., \& Rush H. (2007). Learning to manage mega projects: the case of BAA and Heathrow terminal 5, Project Perspectives, Vol. XXIX, 2007, pp. 32-39

Chapman C. B., \& Ward S. (2002). Managing project risk and uncertainty: a constructively simple approach to decision making, Wiley, New York

Chapman C. B., \& Ward S. (2003). Project risk management: processes, techniques \& insights, 2nd Edition, Wiley, New York

Cherns A. B., \& Bryant D. T. (1984). Studying the client's role in construction management, Construction Management and Economics, 2(2): 177-184

Chesbrough H. W. (2003). Open innovation: the new imperative for creating and profiting from technology, Harvard Business School Press, Boston, MA 
Chesbrough H. (2006). Open business models: how to thrive in the new innovation landscape, Harvard Business School Press, Boston, MA

Chesbrough H., \& Rosenbloom R. S. (2002). The role of business model in capturing value from innovations: evidence from Xerox Corporation's technology spin-off companies. Industrial and Corporate Change, 11(3): 529-555

Chesbrough H., Vanhaverbeke W., \& West J. (2006). Open innovation: the researching a new paradigm, Oxford University Press, New York

Clegg S. R., Pitsis T. S., Marosszeky M., \& Rura-Polley T. (2006). Making the future perfect: constructing the Olympic dream, 265-293, In: Hodgson D., \& Cicmil, S., 2006a: Making projects critical, Basingstoke, UK, Palgrave MacMillan

Cleland D. I., \& King W. R. (1968). Systems analysis and project management, McGrawHill, New York

Coase R. H. (1937). The nature of the firm, Economica, 4: 386-405

Cooper R. G., Edgett S. J., \& Kleinschmidt E. J. (1997a). Portfolio management in new product development: lessons from the leaders - I, Research Technology Management, September-October, 16-28

Cooper R. G., Edgett S. J., \& Kleinschmidt E. J. (1997b). Portfolio management in new product development: lessons from the leaders - II. Research Technology Management, November-December, 43-52

Cooper R. G., Edgett S. J., \& Kleinschmidt E. J. (1998a). Portfolio management for new products, Perseus Books, Cambridge, MA

Cooper R. G., Edgett S. J., \& Kleinschmidt E. J. (1998b). Best practices for managing R\&D portfolios, Research Technology Management, July_August, 20-33

Cova B., Ghauri P., \& Salle R. (2002). Project marketing: beyond competitive bidding, John Wiley \& Sons Ltd

Cova B., \& Hoskins S. (1997). A twin-track networking approach to project marketing, European Management Journal, 15(5): 546-556

Cova B., Mazet F., \& Salle R. (1993). In M. J. Baker (Ed.), Towards flexible anticipation: the challenge of project marketing. Perspectives on marketing management, Vol. 3., Wiley \& Sons, Ltd., New York

Cova B., Mazet F., \& Salle R. (1994). From competitive tendering to strategic marketing: an inductive approach for theory-building. Journal of Strategic Marketing, 2: 29-47

Cova B., Mazet F., \& Salle R. (1996). Milieu as the pertinent unit of analysis in project marketing, International Business Review, 5(6): 647-664 
Daft R.L., \& Lengel R.H. (1986). Organizational information requirements, media richness and structural design, Management Science, 32(5): 554-571

Daft R.L., \& Macintosh N.B. (1981). A tentative exploration into the amount of equivocality of information processing in organizational work units, Administrative Science Quarterly, 26(2): 207-224

Dahlander L., \& Wallin M. W. (2006). A man on the inside: unlocking communities as complementary assets, Research Policy, 35: 1243-1259

Dammer H., \& Gemünden H.G. (2007). Improving resource allocation quality in multiproject environments: evaluating the effects of coordination mechanisms. European Academy of Management Conference EURAM, 16-19 May, 2007, Paris, France

Davies A. (2004). Moving base into high-value integrated solutions: a value stream approach. Industrial \& Corporate Change, 13: 727-756

Davies A., \& Hobday M. (2005). The business of projects. Managing innovation in complex products and systems. Cambridge University Press, U.K.

Davies A., \& Hobday M. (2006). Strategies for solutions, pp. 132-154, In: Lowe D. (ed.) \& Leiringer R. Commercial management of projects: defining the discipline, Blackwell publishing, UK

Davis P. R. (2006). The application of relationship marketing to construction. Doctoral dissertation, School of Economics, Finance and Marketing. Melbourne, RMIT University

Davis P. R., \& Walker D. H. T. (2008). Case study - trust, commitment and mutual goals in alliances, 378-399, In: Walker D. H. T., \& Rowlinson S. (eds.): Procurement systems - a cross industry project management perspective, Abingdon, Oxon, Taylor \& Francis

DeFillippi R.J., \& Arthur M.B. (1998). Paradox in Project-Based Enterprice: The case of Film Making. California Management Review 40(2):125-139

Dietrich P. (2007). Coordination strategies in organizational development programs, Doctoral Dissertation, Helsinki University of Technology, Department of Industrial Engineering and Management, Espoo, Finland

Dietrich P., Kujala J., Lampenius M., \& Artto K. (2007). Integration of project sales and execution in a global organization, European Academy of Management (EURAM) 2007, 7th Annual Conference, May 16-19, Paris, France

Donaldson T., \& Preston L. E. (1995). The stakeholder theory of the corporation: Concepts, evidence, and implications, Academy of Management Review, 20: 65-91

Doz Y. L., \& Hamel, G. (1998). Alliance advantage - the art of creating value through partnering, Boston, Harvard Business School Press 
Dubois A., \& Gadde L-E. (2000). Supply strategy and network effects - purchasing behaviour in the construction industry, European Journal of Purchasing and Supply Management 6 pp. 207-215

Eccles R. (1981). The quasifirm in the construction industry, Journal of Economic Behavior and Organization, 2: 335-357

Eden C., Williams T., Ackermann F., \& Howick S. (2000). The role of feedback dynamics in disruption and delay on the nature of disruption and delay (D\&D) in major projects, Journal of the Operational Research Society, 51:291-300

Eisenhardt K. M. (1989). Agency theory: an assessment and review, Academy of Management review, 15: 57-74

Elonen S., \& Artto K. A. (2003). Problems in managing internal development projects in multi-project environments, International Journal of project management, 21(6): 395-402

Eloranta K. (2007). Supplier relationship management in networked project business, Licentiate's Thesis, Helsinki University of Technology, Department of Industrial Engineering and Management, Finland

Eloranta K., \& Kujala J. (2008). Stakeholder influence strategies in global projects. Paper submitted to be evaluated for potential publication in the Scandinavian Journal of Management (submitted)

Eloranta K., Kujala J., \& Artto K. (2007). Managing risk in subcontractors' business relationships with client and competitors, Project Perspectives, XXIX(2007): 52-56

Eloranta K., Kujala J., \& Artto K. (2006). Subcontractors' inter-organizational relationships as risk sources in project networks. Proceedings of the Seventh International Conference of the International Research Network on Organising by Projects IRNOP VII, Xi'an, China, October 11-13, 2006, pp. 302-317

Eloranta K., Kujala J., Artto K., \& Tikkanen H. (2006). Suppliers' inter-organizational relationships in project networks. European Academy of Management 2006, 6th Annual Conference, May 17-20, Oslo, Norway

Eloranta K., Kujala J., \& Oijala T. (2008). Stakeholder salience in global projects, International Journal of Project Management (forthcoming)

Eloranta K., \& Sivonen R. (2008). Response strategies to stakeholder pressures in global projects. European Academy of Management EURAM, 8th Annual Conference, May 1417, 2008, Ljubljana \& Bled, Slovenia

Engwall M. (2003). No project is an island: linking projects to history and context, Research Policy, 32(5): 789-808

Engwall M., \& Jerbrant A. (2003). The resource allocation syndrome: the prime challenge of multi-project management?, International Journal of project management, 21(6): 403409 
Evaristo J. R., Scudder R., Desouza K. C., \& Sato O. (2004). A dimensional analysis of geographically distributed project teams: a case study, Journal of Engineering and Technology Management, 21: 175-189

Floricel S., \& Miller R. (2001). Strategizing for anticipated risks and turbulence in largescale engineering projects, International Journal of project management, 19: 445-455

Flyvbjerg B., Bruzelius N., \& Rothengatter W. (2003). Megaprojects and risk: an anatomy of ambition, Cambridge University Press, Cambridge

Freeman R. E. (1984). Strategic management: a stakeholder approach, Pitman, Boston

Galbraith J. R. (1973). Designing complex organizations, Reading: Addison-Wesley

Gann D., \& Salter A. (2000). Innovation in project-based, service-enhanced firms: the construction of complex products and systems, Research Policy, 29(7-8): 955-972

Grabher G., 2002. The project ecology of advertising: tasks, talents, and teams, Regional Studies, 36(3): 245-262

Grabher G., 2004. Architectures of project-based learning: creating and sedimenting knowledge in project ecologies, Organization Studies, 25 (9): 1491-1514

Grün O. (2004). Taming giant projects: management of multi-organization enterprises, Springer, Berlin

Hadjikhani A. (1996). Project marketing and the management of discontinuity, International Business Review, 5(3): 319-336

Haefliger S., von Krogh G., \& Spaeth S. (2008). Code reuse in open source software, Management Science, 54(1): 180-193

Hansson H. (1998) Collective competence, BAS, Gothenburg, Sweden (in Swedish)

Hawk D. L., \& Artto K. A. (1999). Factors impeding project management learning, Project Management, 5(1): 56-67

Helander A. (2004). Customer care in system business, Helsinki School of Economics, Helsinki

Hellgren B., \& Stjernberg T. (1995). Design and implementation in major investments - a project network approach, Scandinavian Journal of Management, (11)4: 377-394

Hellström M. (2005). Business concepts based on modularity: a clinical inquiry into the business of delivering projects, Doctoral Dissertation, Åbo Akademi University, Åbo Akademi University Press, Turku, Finland 
Henderson R., \& Clark K. (1990). Architectural innovation: the reconfiguration of existing product technologies and the failure of established firms, Administrative Science Quarterly, 35: 9-30

Hirvonen V. (2005). Capturing advance demand information from project delivery networks for demand supply planning, Master's Thesis, Helsinki University of Technology, Department of Industrial Engineering and Management, Espoo, Finland

Hobday M. (1998). Product complexity, innovation and industrial organisation, Research Policy, 26: 689-710

Hobday, M. (2000). The project-based organisation: an ideal form for managing complex products and systems?, Research Policy, 29: 871-893

Hobday M., Davies A., \& Prencipe A. (2005). Systems integration: a core capability of the modern corporation, Industrial and Corporate Change, 14(6): 1109-1143

Hodgson D., \& Cicmil S. (2006a). Making projects critical, Basingstoke, UK, Palgrave MacMillan

Hodgson D., \& Cicmil S. (2006b). Are projects real? The PMBOK and the legitimation of project management knowledge, 29-50, In: Hodgson D., \& Cicmil, S., 2006a: Making projects critical, Basingstoke, UK, Palgrave MacMillan

Horii T., Yan J., \& Levitt R. E. (2004). Modeling and analyzing cultural influences on project team performance, Journal of Computational and Mathematical Organization Theory, 10(4): 305-321

Hägg I., \& Johansson J. (1987). Firms in networks: a network perspective on competitive power, SNS, Stockholm

Håkansson H., Havila V., \& Pedersen A. (1999). Learning in networks, Industrial Marketing Management, 28(5): 443-452

Jamieson A., \& Morris P. W. G. (2004). Moving from corporate strategy to project strategy, In: Morris P. W. G., \& Pinto J. K. (Eds.) The wiley guide to managing projects, John Wiley \& Sons Inc., London, U. K., pp. 177-205

Johnson G., \& Scholes K. (1999). Exploring corporate strategy, Prentice Hall Europe, London

Jones C., Hesterly W. S., \& Borgatti S. P. (1997). A general theory of network governance: exchange conditions and social mechanisms, Academy of Management Review, 22(4): 911-945

Keegan A., \& Turner J. R. (2002). The management of innovation in project-based firms, Long Range Planning, 35: 367-388 
Kelly J. (2006). Value management in complex projects, pp. 298-316, In: Lowe D., (ed.) \& Leiringer R. Commercial management of projects: defining the discipline, Blackwell publishing, UK

Kharbanda O. P., \& Pinto J. K. (1996). What made gertie gallop? Lessons from project failures, Van Nostrand Reinhold, New York, USA

Klakegg O. J., Williams T., \& Magnussen O. M. (2007). Design of innovative governance frameworks for public investment projects; comparison between UK and Norway. Eighth International Conference of the International Research Network on Organising by Projects, IRNOP VIII Research Conference, September 19-21, 2007, Brighton, U. K.

Klemetti A. (2006). Risk management in construction project networks, Helsinki University of Technology (HUT), Industrial Management, Report no: 2006/2, Espoo/Finland

Kujala J., Ahola T., Westerholm T., Lehtonen M., Laitinen E., \& Artto K. (2007). Performance measurement in project business networks, Eighth International Conference of the International Research Network on Organising by Projects, IRNOP VIII Research Conference, September 19-21, 2007, Brighton, U. K.

Kujala J., \& Artto K. A. (2000). Criteria for project performance in business context, Project Management, 6(1): 46-53

Kujala J., Artto K., \& Parhankangas A. (2007). Towards theory of project business, 19th Nordic Academy of Management Conference (NFF), August 9-11 2007, Bergen, Norway

Kujala J., Artto K., Wikström K., \& Kujala S. (2008). The role of services in the business of a project-based firm. PMI 2008 research conference, Project Management Institute PMI,13-16 July, 2008, Warsaw, Poland

Kujala J., Murtoaro J., \& Artto K. (2007). A Negotiation approach to project sales and implementation, Project Managemement Journal, 38(4): 33-44.

Kähkönen K., \& Artto K. A. (eds.). (1997). Managing risks in projects, E \& FN Spon, an imprint of Thomson Professional ITP, London, UK, 375 p.

Kähkönen K., Karvonen I., \& Ollus M. (2007). Modelling of networked construction operations, Proceedings of Second International Conference World of Construction Project Management, October 2007, Delft, The Netherlands

Kärkkäinen M., Holmström J., Främling K., \& Artto K. (2002). Intelligent products - a step towards a more effective project delivery chain, Computers in Industry, 50(2): 141151

Laitinen E. (2007). Customer value in turkey project deliveries: A study on the value creation from the buyer's viewpoint and empirical evidence from the Finnish marine industry. Helsinki University of Technology (HUT), Industrial Management, Report no: 2007/1, Espoo/Finland 
Lampel J. (2001). The core competencies of effective project execution: the challenge of diversity, International Journal of Project Management, 19: 471-483

Lampenius M. (2006). Organizing the interface between project marketing and execution in a global organization, Helsinki University of Technology (HUT), Industrial Management, Report no: 2006/4, Espoo/Finland

Lawrence P. R., \& Lorsch J. W. (1967). Organization and environment: managing differentiation and integration, Harvard Business School Press, Boston (MA)

Lehtonen P., \& Martinsuo M. (2008). Change program initiation: defining and managing the program - organization boundary, International Journal of Project Management, 26(1): $21-29$

Levitt B., \& March J. G. (1995). Chester I. Barnard and the intelligence of learning. In: Williamson O.E. (Ed.) Organization theory: from Chester Barnard to the present and beyond, Oxford University Press, New York, 11-37

Lindkvist L. (2004). Governing project-based firms: Promoting market-like processes withing hierarchies. Journal of Management and Governance 8:3-25

Lundin R. A. (1995). Temporary organizations and project management, Editorial, Scandinavian Journal of Management, 11(4): 315-318

Lundin R. A., \& Söderholm A. (1995). A theory of temporary organization, Scandinavian Journal of Management, 11(4): 437-455.

Mahalingam A. (2005). Understanding and mitigating institutional costs on global projects, Doctoral dissertation, department of Civil and Environmental Engineering, Stanford University

Mahalingam A., \& Levitt R. E. (2007). "Institutional theory as a framework for analyzing conflicts on global projects, ASCE Journal of Construction Engineering and Management, 133(7): 517-528

Mandják T., \& Veres Z. (1998). The D-U-C model and the stages of the project marketing process, In: Halinen K., Nummela. (Ed.) 14th IMP annual conference proceedings (pp. 471-490), Turku School of Economics and Business Administration, Turku, Finland

Maqsood T., Finegan A., \& Walker D. H. T. (2006). Applying project histories and project learning through knowledge management in an Australian construction company, The Learning Organization, 13(1): 80-95

Maqsood T., Walker D. H. T., \& Finegan A. D. (2007). Extending the "knowledge advantage": creating learning chains, The Learning Organization, 14(2): 123-141

Martinsuo M., \& Lehtonen P. (2007a). Role of single-project management in achieving portfolio management efficiency, International Journal of project management, 25(1): 5665 
Martinsuo M., \& Lehtonen P. (2007b). Context and action in initiating organizational change programs. Paper presented at IRNOP VIII International Research Network on Organizing by Projects Conference, 19-21 September, 2007, Brighton, UK

Martinsuo M., \& Lehtonen P. (2007c). Program initiation in practice: development program initiation in a public consortium, International Journal of Project Management, 25 (4): $337-345$

McCord K., \& Eppinger S. (1993). Managing the integration problem in concurrent engineering, working paper, Cambridge, MA

McGrath R. G., \& MacMillan I. (2000). The entrepreneurial mindset: strategies for continuously creating opportunity in an age of uncertainty, Harvard Business School Press, Boston, Massachusetts (380 p.)

Meklin J., Lahti M., Artto K. A., \& Arenius M. (1999). The power of product management in project business, In: Artto K. A., Kähkönen K., \& Koskinen K. (eds.) Managing business by projects, Project Management Association Finland and Nordnet, Vol. 1. \& Vol. 2, 1298 p., Vol. 1., pp. 596-607

Meklin J., Lahti M., Kovanen V., Arenius M., \& Artto K. (1999). FIT-PRO - a productoriented approach to industrial project management, Project Management Association Finland, Helsinki, 94 p.

Miller R. (2006). Principles of governance for major investments projects, Concept Symposium 2006, Sept 7-8, 2006, Norwegian University of Science and Technology NTNU, Trondheim, Norway

Miller R., Hobday M., Leroux-Demers T., \& Olleros X. (1995). Innovation in complex systems industries: the case of flight simulation, Industrial \& Corporate Change, 4: 363400

Miller R., \& Lessard D. (2001)a. The strategic management of large engineering projects: shaping risks, institutions and governance, MIT Press, Cambridge, MA

Miller R., \& Lessard D. (2001)b. Understanding and managing risks in large engineering projects, International Journal of project management, 19: 437-443

Mintzberg H., Quinn J. B., \& Ghoshal S. (1995). The strategy process, Prentice Hall London

Mitchell R. K., Agle B.R., \& Wood D. J. (1997). Toward a theory of stakeholder identification and salience: defining the principle of who and what really counts, Academy of Management Review, 22(4): 853-886.

Moffat J. (2003). Complexity theory and network centric warfare. DoD Command and Control Research Program CCRP publication series, U.S. (can be downloaded from the Program's website at http://www.dodccrp.org/ -> book downloads) 
Morris P. W. G. (1983). Managing project interfaces - key points for project success, pp. 336, In: Cleland D. I., \& King W. R. (eds.). (1983). Project management handbook, Van Nostrand, New York

Morris P. W.G. (1994). The management of projects, Thomas Telford, London, UK

Morris P.W.G., Crawford L., Hodgson D., Shepherd M. M., \& Thomas J. (2006).

Exploring the role of formal bodies of knowledge in defining a profession - the case of project management, International Journal of Project Management, 24: 710-721

Morris P. W. G., \& Hough G. H. (1987). The anatomy of major projects - a study of the reality of project management, John Wiley \& Sons, Chichester

Morris P., \& Jamieson A. (2004). Translating corporate strategy into project strategy: realizing corporate strategy through project management, Project Management Institute, Newtown Square, Pennsylvania

Morris M., Schindehutte M., \& Allen J. (2005). The entrepreneur's business model: toward a unified perspective, Journal of Business Venturing, 58: 726-735

Murtoaro J. (2006). Public-private partnerships: a study on the economic and financing alternatives of transport infrastructure production, Helsinki University of Technology (HUT), Industrial Management, Report no: 2006/3, Espoo/Finland

Murtoaro J., \& Kujala J. (2007). Project negotiation analysis. International Journal of Project Management, 25: 722-733

Müller R., Martinsuo M., \& Blomquist T. (2008). Project portfolio control and portfolio management performance in different contexts. Project Management Journal (forthcoming)

Nieminen A., \& Lehtonen M. (2008). Organisational control in programme teams: an empirical study in change programme context, International Journal of Project Management, 26(1): 63-72

Oliva R., \& Kallenberg R. (2003). Managing the transition from products to services, International Journal of Service Industry Management, 14(2)

Oosterman B. (2001). Improving product development projects by matching product architecture and organization, doctoral thesis, University of Groningen, The Netherlands

Orr R. J. (2005). Unforeseen conditions and costs on global projects: learning to cope with unfamiliar institutions, embeddedness and emergent uncertainty, doctoral dissertation, department of Civil and Environmental Engineering, Stanford University

Owusu R. A. (2003). Collective network capability in international project business networks. A case study of the business network for the Ashanti Electrification Project in Ghana. Doctoral Dissertation, Publications of the Swedish School of Economics and Business Administration, Helsinki, Finland 
Packendorff J. (1995). Inquiring into the temporary organization: new directions for project management research, Scandinavian Journal of Management, 11(4): 319-334

Patanakul P., Shenhar A. J., \& Milosevic D. (2006). Why different projects need different strategies. Proceedings of the PMI Research Conference, 16-19 July, 2006, Montreal, Canada: Project Management Institute, Pennsylvania.

Pellegrinelli S., Partington D., Hemingway C., Mohdzain Z., \& Shah M. (2007). The importance of context in programme management: an empirical review of programme practices, International Journal of Project Management, 25(1): 41-55

Perminova O., Gustafsson M., \& Wikström K. (2008). Defining uncertainty in projects - a new perspective, International Journal of Project Management, 26(1):73-79

Pimmler T., \& Eppinger S. (1994). Integration analysis of product decompositions, Proceedings of the ASME Design Theory and Methodology Conference, Minneapolis, MN

Porter M. E. (1998). Clusters and the new economics of competition, Harvard Business Review, 76 (6): 77-90

Powell W.W. (1987). Hybrid organizational arrangements: new form or transitional development. Organizational Approaches to Strategy. Ballenger Publishing Company, Cambridge

Powell W.W. (1990). Neither market nor hierarchy: network forms of organization, Research in organizational behavior, 12: 295-336

Prencipe A., \& Tell F. (2001). Inter-project learning: processes and outcomes of knowledge codification in project-based firms, Research Policy, 30(9): 1373-1394

Rowley T.J. (1997). Moving beyond dyadic ties: a network theory of stakeholder influences, The Academy of Management Review, 22(4): 887-910

Ruuska I. (2005) Social structures as communities for knowledge sharing in project-based environments. Helsinki University of Technology, Work Psychology and Leadership, Doctoral Dissertation Series 2005/3, Espoo

Ruuska I., Artto K., Eloranta K., \& Lehtonen P. (2008). Dimensions of a distance in a network of firms: exploring Olkiluoto 3 nuclear power plant project, European Academy of Management EURAM, 8th Annual Conference, May 14-17, 2008, Ljubljana \& Bled, Slovenia

Samset K. (2003). Project evaluation. Making investments succeed, Tapir Academic Press, Trondheim

Sandberg J., \& Targama A. (1998). Leading and understanding, Studentlitteratur, Lund, Sweden (in Swedish)

Sayles L. R., \& Chandler M. K. (1971). Managing large systems: organizations for the future, Harper \& Row, New York 
Scott W. R. ed. (2008). Global projects: institutional and political challenges, forthcoming

Shenhar A. J. (2001). One size does not fit all projects: exploring classical contingency domains, Management Science, 47(3): 394-414

Shenhar A. J., \& Dvir D. (2004). How projects differ and what to do about it, pp 1265 1286, In: Morris P. W. G., \& Pinto J. K. (eds.) "The Wiley guide to managing projects", John Wiley \& Sons Inc., London

Shenhar A. J., \& Dvir D. (2007). Reinventing project management: the diamond approach to successful growth and innovation, Harvard Business School Press, Boston,

Massachusetts

Shenhar A. J., Dvir D., Guth W., Lechler T., Patanakul P., Poli M. \& Stefanovic J. (2005). Project strategy: the missing link. Paper presented at the annual Academy of Management meeting, 5-10 August, 2005, Honolulu, HI, USA

Shenhar A. J. , Milosevic D., Dvir D., \& Thamhain H. (2007). Linking project management and business strategy, Project Management Institute, PA

Skaates M. A. (2000). Danish architectural sales to Germany in the 1990s: an IMP/INPM approach to examining the professional service and project-related internationalization of Danish architectural service firms. Doctoral Dissertation, Copenhagen Business School, Copenhagen

Skaates M. A., \& Tikkanen H. (2003). International project marketing as an area of study. A literature review with suggestions for research and practice, International Journal of Project Management, 21(1): 503-510

Slevin D. P., \& Pinto J. K. (1987). Balancing strategy and tactics in project implementation, Sloan Management Review, 29(1): 33-41

Sosa M., Eppinger S., \& Rowles C. (2003). Identifying modular and integrative systems and their impact on design team interactions, Journal of Mechanical Design, 125: 240-242

Spina G. \& Zotteri G. (2000). The implementation of customer-supplier partnership: lessons from a clinical perspective, International Journal of Operations and Production Management, (20)10: 1164-1182

Stewart D.W., Zhao Q. (2000). Internet marketing, business models, and public policy, Journal of Public Policy and Marketing, 19: 287- 96

Stinchcombe A. L., \& Heimer C. A. (1985). Organization theory and project management administering uncertainty in Norwegian offshore oil, Norwegian University Press, Oslo

Sydow J., Lindkvist L., \& DeFillippi R. (2004). Project-based organizations, embeddedness and repositories of knowledge. Organization Studies 25(9):1475-1490

Sydow J., \& Staber U., 2002. The institutional embeddedness of project networks: 
the case of content production in German television, Regional Studies 36 (3): 215-227

Söderlund J. (2002). Managing complex development projects: arenas, knowledge processes and time, R\&D Management, 32(5): 419-430

Söderlund J. (2004). On the broadening scope of the research on projects: a review and a model for analysis, International Journal of project management, 22(8): 655-667

Thompson J. D. (1967). Organizations in action: social science bases of administrative theory, New York, McGraw-Hill

Tikkanen H. (1998). Research on international project marketing. A review and implications. In: Tikkanen H.(Ed.) Marketing and international business, essays in honour of Professor Karin Holstius on her 65th birthday (pp. 261-285), Turku School of Economics and Business Administration

Tikkanen H., Kujala J., \& Artto K.A. (2007). The marketing strategy of a project-based firm: the four portfolios framework, Industrial Marketing Management, 36(2): 194-205

Turner J. R., \& Cochrane R. A. (1993). The goals and methods matrix: coping with projects with ill-defined goals and/or methods of achieving them, International Journal of Project Management, 11(2): 93-102.

Turner J. R., \& Keegan A. (2001). Mechanisms of governance in the project-based organization: roles of the broker and steward, European Management Journal, 19(3): 254267

Turner J. R., \& Müller R. (2003). On the nature of the project as a temporary organization, International Journal of Project Management, 21: 1-8

Turner J., \& Simister S.J. (2001). Project contract management and theory of organization, International Journal of Project Management, 19: 457-464

Walker D. H. T., Bourne L., \& Rowlinson S. (2008). Stakeholders and the supply chain, In: Walker D. H. T., \& Rowlinson S. Eds. Procurement systems - a cross industry project management perspective, Taylor \& Francis, London

Walker D. H. T., Rowlinson S. (Eds.). (2008). Procurement systems - a cross industry project management perspective, Abingdon, Oxon, Taylor \& Francis

Walker C., \& Smith, A. J. (1995). Privatised infrastructure - the BOT approach, London, Thomas Telford

Whitley R. (2006). Project-based firms: new organizational form or variations on a theme?, Industrial and Corporate Change, 15(1): 77-99

Wikström K., Hellström M., Artto K., Kujala J., \& Kujala S. (2008). Drivers and barriers for adopting services in project-based firms, European Academy of Management EURAM, 8th Annual Conference, May 14-17, 2008, Ljubljana \& Bled, Slovenia 
Williams T. (2002). Modeling complex projects, John Wiley \& Sons, Chichester, UK

Williams T., Ackermann F., \& Eden C. (2003). Structuring a delay and disruption claim: an application of cause-mapping and system dynamics, European Journal of Operational Research, 148: 192-204

Williams T., Eden C., Ackermann F., \& Tait A. (1995). Vicious circles of parallelism, International Journal of Project Management, 13(3): 151-155

Williamson O. E. (1985). The economic institutions of capitalism, Free Press, New York

Winch G.M. (2004). Managing project stakeholders, In: Morris P. W. G., \& Pinto J.K. (Eds.) The wiley guide to managing projects, John Wiley \& Sons Inc., Wiley, New Jersey

Winch G. M. (2006). The governance of project coalitions - towards a research agenda, pp. 324-343, In: Lowe D., (ed.) \& Leiringer R. Commercial management of projects: defining the discipline, Blackwell publishing, UK

Winch G.M., \& Bonke S. (2002). Project stakeholder mapping: analyzing the interests of project stakeholders, In: Slevin D.P., Cleland D.I., \& Pinto J.K. (Eds.) The frontiers of project management research, Project Management Institute

Windeler A., \& Sydow J., 2001. Project networks and changing industry practice: collaborative content production in the german television industry, Organization Studies, 22 (6): 1035-1060

Winter M., Smith C., Morris P. W. G., \& Cicmil S. (2006). Directions for future research in project management: the main findings of a UK government-funded research network, International Journal of Project Management, 24(8): 638-649

Wise R., \& Baumgartner P. (1999). Go downstream: the new profit imperative in manufacturing, Harvard Business Review, 77: 133-141

Zika-Viktorsson A., Sundström P., \& Engwall M. (2006). Project overload: an exploratory study of work and management in multi-project settings, International Journal of project management, 24(5): 385-394 